\title{
The Environmental Impact Study Of Micro Hydro Power In Pekalongan Indonesia
}

\author{
Suwarto $^{1 *}$, Sudharto P Hadi ${ }^{2}$ and Hermawan ${ }^{3}$ \\ ${ }^{1}$ Doctoral Program of Environmental Science, School of Postgraduate Studies, Diponegoro University, Semarang - Indonesia \\ ${ }^{2}$ Department of Environmental Science, Diponegoro University, Semarang - Indonesia \\ ${ }^{3}$ Faculty of Engineering of Diponegoro University, Semarang - Indonesia
}

\begin{abstract}
Curugmuncar II micro hydro power (MHP) located in Petungkriyono sub district is one of three MHPs installed in Pekalongan district. This study aims to analyze the MHP operation environmental impact. The study used qualitative method, with interviews, observations, and material testing. The data used are primary and secondary data. This research was conducted in Curugmuncar Village, Petungkriyono Subdistrict, Pekalongan Regency, Indonesia. MHP has power capacity of $100 \mathrm{KW}$ with power usage of 50 KW. MHP used by 155 users with load capacity 2 A 220 volt AC. The community more used of lights as the houses and street lighting. The MHP operation had several environmental factors such as: sociology, technically feasible, hydrology, physical and chemical water quality, ergonomics, economically feasible, irrigation, clean water supply, government policy, and others. The supporting factors sustainability of MHP were sociology, irrigation, ergonomics, clean water supply, physical and chemical water quality, hydrology, and government policy. The inhibiting factors of MHP operation were technically feasible, economically feasible, and government policy. The results showed that the MHP environment requires a professional management system to achieve the MHP sustainability
\end{abstract}

\section{Introduction}

Energy plays an important role in a country's economy. Renewable energy sources are potential solutions to meet energy needs, especially in rural areas. The use of renewable energy is considered to contribute to reducing the impacts of climate change and environmental degradation [1].

Data from the statistics of Indonesia's EBTKE related to renewable energy and energy conservation (2016) showed that the new renewable energy mix in Indonesia has increased by an average of $0.36 \%$ annually. The new renewable energy mix as primary energy source still occupies the lowest position with a percentage of $6.2 \%$ compared to $43.0 \%$ for petroleum, $28.7 \%$ for coal and $22.0 \%$ for natural gas by 2015 . The achievement of new renewable energy has increased since 6 Last year, In 2010, the renewable energy (RE) achievement of electricity amounted to 48,184,711 barrel of oil equivalent (BOE) and continued to increase until reaching $73,497,500$ BOE by 2015 .

New renewable energy potentials in Indonesia are abundant as water, wind or wind, solar and bioenergy. Most of Indonesia is waters and mountains. Many areas of Indonesia have the potential for forests and mountains that are the source of water. The potential of hydro power in Indonesia is 75,091 MW, with the potential of hydro power in Central Java province at 813 MW. The micro hydro potential in Central Java Province is 1,044 MW with total micro hydro potential in Indonesia of 19,385 MW. In Indonesia there are about 41 micro hydro power built in various regions with total energy capacity of 134.21 MW [2].

The electricity aspect in Indonesia is managed by a State-Owned Enterprise, namely Perusahaan Listrik Negara PT. PLN. Indonesia's electrification ratio in 2015 was $88.30 \%$. That is, there are still $11.7 \%$ of the area in Indonesia that is still not yet powered by electricity. The government targets electrification ratio in 2019 of $97.35 \%$ [3]. The number of villages in Indonesia is 74,093 villages with 39,086 of them including lagging villages, and 17,268 villages are underdeveloped. According to data from the Central Bureau of Statistics in 2015 as many as 2519 villages have not electricity, and as many as 20,493 villages using electricity non PLN, and amounted to 69,531 have access to PLN electricity [4].

Electricity is a key strategic in the equity of social justice that has an effect on improving people's lives. One of the obstacles to the provision of rural electricity access to rural areas is quite difficult, especially in mountainous areas, such as in Curugmuncar Village, Pekalongan Regency, Indonesia. Specifically, through the program of 
the Ministry of Energy and Mineral Resources in Indonesia has provided funding for the construction of micro hydro power in rural areas that have not yet electricity.

The benefits of electrical energy are enormous in human life. The goal of rural electrification programs in developing countries is to realize socio-economic development of households [5]. Electrical energy has a very important role in various industrial sectors such as education, health, food. So that electric energy can have an impact on economic development in a region. A study conducted by Uduak Akpan et al to find out the impact of rural electrification on the development of rural SMEs in the Niger Delta, Nigeria, that small rural industries connected to power grids are $16.2 \%$ more profitable than small rural industries not connected to power lines. The study also shows that micro-business owners are fully aware that access to electricity is critical and affects the profitability of their businesses [6].

Rural electrification is also assessed to serve socioeconomic development goals. Increased access to electricity can encourage rural industry, increase agricultural productivity, and provide productive time for children to study at night, and not close the possibility for people to work at night [7].

Many international organizations are calling for increased use of renewable energy in an effort to reduce $\mathrm{CO}_{2}$ emissions and tackle climate change. The results of previous studies conducted by Brantley Liddle and Perry Sadorsky (2017) that a one percent increase of the share of non-fossil fuel power plants reduces $\mathrm{CO}_{2}$ emissions per capita from power plants by about $0.82 \%$ [8]

Indonesia is targeting to build micro hydro power (MHP) from 2010-2014 with an average capacity of 85 MW / year and 2015-2019 with an average capacity of 127 MW / year. Curugmuncar II MHP installed in 20102014 with an average capacity of $100 \mathrm{MW} /$ year. The development of MHP in Indonesia in the period 20102014 exceeded the target by $15 \%$. Thus, the development of MHP in Indonesia has the potential to become a sustainable source of renewable energy sources. This study aims to make an environmental agreement about operating MHP in Curugmuncar pekalongan.

\section{Materials and Methods}

The method used is qualitative with interview and observation. The data used are primary data and secondary data. This research conducted in Curugmuncar Village, Petungkriyono Sub district, Pekalongan Regency, Indonesia in May 2017. The object of research is Curugmuncar II MHP which started to operate in 2010. Aspects analyzed in this research include Sociology aspect, technical feasibility, policy Government hydrology, river water quality, ergonomics, clean water supply and irrigation, and other environmental aspects. This research use descriptive qualitative approach. The data used in this study are primary data and secondary data. Primary data were obtained from interviews, observation, and laboratory testing. While the secondary data obtained from the results of literature review obtained from scientific journals, the study of Meteorology and Geophysics Agency, as well as studies in the field of Mineral Resource Energy.

Interviews conducted to obtain the information such as current state of MHPs, informants of this research were managers of the MHPs and villages heads. At the time of observation, the researcher made an observation on the environmental aspects of MHP in Curugmuncar Village and collected data on everything related to the operation of MHP, electricity distribution, interaction between the community and the management, the behavior of the local people's electricity usage. Data analysis used qualitative descriptive method to describe phenomenon that occurred in Curugmuncar II MHP based on variables that have been studied. In addition, observation data are presented in graphs and percentages.

In this study also conducted analysis through economic and technical approach with the following calculation formula:

Total profit of MHP without decrease of investment value Profit $=$ total income - operational costs

Total profit of MHP with decrease of investment value

$=$ Total income $-($ operating costs + decreased investment $)$

Furthermore, we also conducted a mathematical analysis to determine the reliability of a system, reliability is defined as "the ability of an item to perform a required function, under given environmental and operational conditions and for a stated period of time". Reliability of a system can be known by calculation (Mean Time to Failure, number of failures in some time interval, and others) $[9,10]$.

\section{Mean Down Time (MDT)}

"Mean Downtime (MDT) is the average Total Downtime required to restore an asset to its full operational capabilities. MDT includes the time from reporting of an asset being down to the asset being given back to operations / production to operate"[11].

\section{Mean Time Between Failure (MTBF)}

"MTBF is the mean operating time (up time) between failures of a specified item of equipment or a system. MTBF (years, hours) is most often used to express the overall reliability of equipment" [12].

Following is the formula used to calculate MTBF,

$$
\begin{gathered}
M T B F=\frac{\text { Total operating time }}{\text { Number of failures }} \\
\lambda=\frac{\text { Number of failures }}{\text { Total operating time }} \\
M T B F=\frac{1}{\lambda}
\end{gathered}
$$

“ $\lambda$ (hr-1, pmh, FITs) - is convenient to use for components, and it is easy to calculate the MTBF of an item of equipment from the sum of the component $\lambda \mathrm{s}$." 


\section{Mean Time To Repair (MTTR)}

"Mean Time To Repair (MTTR) is the time needed to repair a failed hardware module. In an operational system, repair generally means replacing a failed hardware part (S. Stanley, 2011)."

Following is the formula used to calculate MTTR :

$$
M T T R=\frac{\text { Total Maintenance Time }}{\text { Numbers of Repairs }}
$$

\section{Operational Availability}

Following is the formula used to calculate Operational Availability,

$$
\text { Operational availability }=\frac{\mathrm{MTBM}}{M T B M+M D T}
$$

Where "MTBM is mean time between corrective and preventive maintenance actions" [13]

\section{Forced Autage Rate (FOR)}

Forced outages is "when unit (s) is out of service due to failure called also unscheduled (unplanned) outage" [14] The formula used to calculate FOR is,

$$
F O R=\frac{\text { Time unit is on forced outages }}{\text { Time unit on service }+ \text { Time on outages }}
$$

\section{Results and Discussions}

Curugmuncar II MHP was built in Curugmuncar Village, Petungkriyono Subdistrict, Pekalongan Regency which is $48 \mathrm{~km}$ distance from the district center, and $7 \mathrm{~km}$ from the center of the district. Curugmuncar II MHP is located at an altitude of 1300 MDPL with an ambient air temperature ranging from $18-30^{\circ} \mathrm{C}$. Curugmuncar II MHP has a capacity of $100 \mathrm{KW}$ with power used $50 \mathrm{KW}$. Curugmuncar II MHP is used by $155 \mathrm{KK}$ with load capacity 2 A 220 volt AC. Curugmuncar II MHP is built in forest and plantation areas. Community forest area of $13,000 \mathrm{Ha}$, state forest $341.142 \mathrm{Ha}$, state or private plantation $1.107 \mathrm{Ha}$, and garden as much as $56.110 \mathrm{Ha}$.

Curugmuncar II MHP was built in 2008 and started to operate in 2010 . The length of the water flow is 600 meters with the length of the river built 400 meters and the length of the pipe 200 meters with a diameter of $60 \mathrm{~cm}$. Initially, the water of Curugmuncar II was used as agricultural irrigation, but after 2012 Curugmuncar I MHP was built. This proves that the water of MHP can still be used to generate more energy. Residents utilize water from dams for daily uses such as cooking, drinking, washing, bathing, etc. While spillway is used for agricultural irrigation channel and put into steam Curugmuncar MHP. Penstock passes the agricultural path of citizen and slightly disrupt agricultural activity.

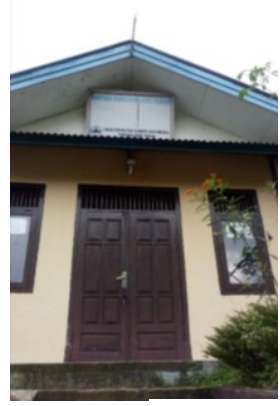

(a)

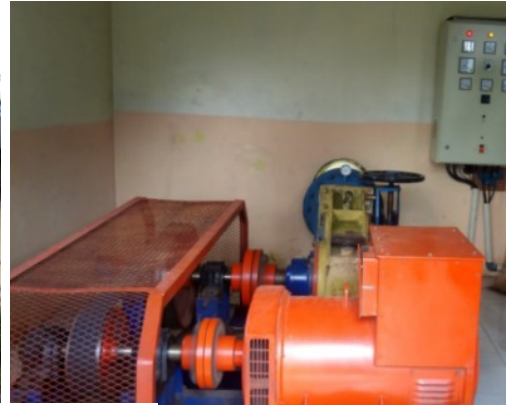

(b)
Fig. 1. (a) Power House of Curugmuncar II MHP (b) Generator

\section{Sociology Aspects}

As many as $16 \%$ of users feel very satisfied with the existence of MHP; $74 \%$ of MHP electricity users were satisfied. As many as $90 \%$ of MHP's were happy and proud of the MHP existence in their village. In addition, they also revealed that that became one aspect of this community acceptance due to the process of cheap electricity payment and no problem if they pay late. This means no specific sanctions from the manager for users who have not paid the electricity charge at the time specified. In addition, the community is very happy with the existence of MHP because it can build the economy and education in their village. Some users revealed that after the existence of electricity MHP then they can open a sewing business, furniture, electric welding, and also increase educational and religious activities.

As many as $6 \%$ feel quite satisfied; $4 \%$ not satisfied with MHP power. As many as $10 \%$ of users who were less satisfied with this MHP stated that they want electricity from PLN for various reasons. According to them, by using PLN electricity, electricity problems die during floods or landslides will not interfere with their daily activities. Usually, if MHP's electricity dies due to flood or landslide, it can take days to make improvements. Surely this is quite disturbing community activities.

Level of Satisfaction of the MHP's Electricity users

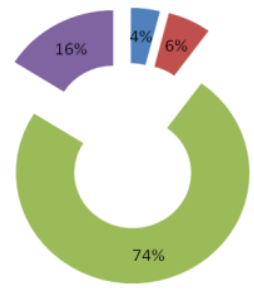

- Un satisfied

n Quite satisfied

= Satisfied

- Very satisfied

Fig. 2. Aspects of Public Acceptance of MHP's Electricity Users

The existence of Curugmuncar II MHP since 2010 has changed the behavior of community in Curugmuncar village. Until now people's lives have grown in the presence of electricity. Society has known technology such as television, mobile phone, computer, and others. Therefore, information and communication technology that enter into this area is a positive impact of the 
existence of MHP electricity. Today's society can get information from things they need more easily. The community uses more lights as the lighting of houses and roads. The types of lights used by the community are fluorescent lights, LEDs, and tungsten bulb. Type of TV used is plasma TV, LCD TV. Types of communication tools used are smartphone, parabola, mobile phone, laptop, modem. Types of work equipment used are electrical, electrical, electrical sewing machines. Household appliances used are refrigerator, fan, blender, mixer, magic com.

\section{Economics Feasibility Aspects}

The total income of MHP was 14979.30 USD with operating costs was 4821.23 USD. Based on the calculation, the total profit of MHP without decreasing investment value was 10158.07 USD.

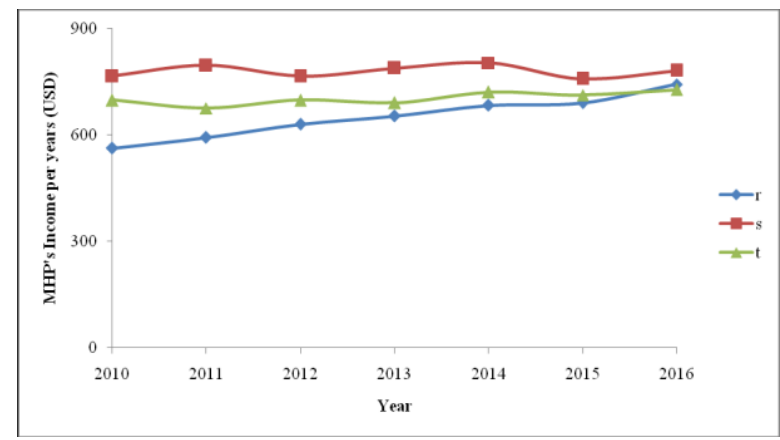

(a)

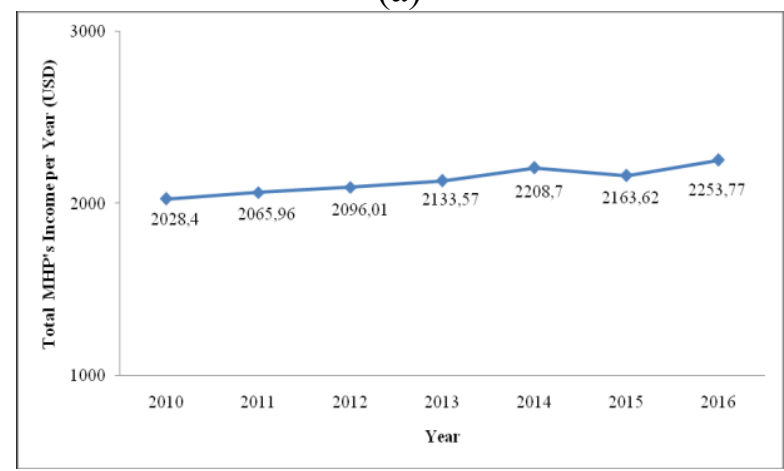

(b)

Fig. 3. (a) MHP's income per years according to R,S,T ; (b) Total MHP's income per year

The investments decrease were 9995.83 USD. From the calculation results obtained the total MHP profit with the decreased of investment value were 162.25 USD. This value indicates that MHP Curugmuncar II is not feasible for profit aspect but for sustainability aspect is still feasible.

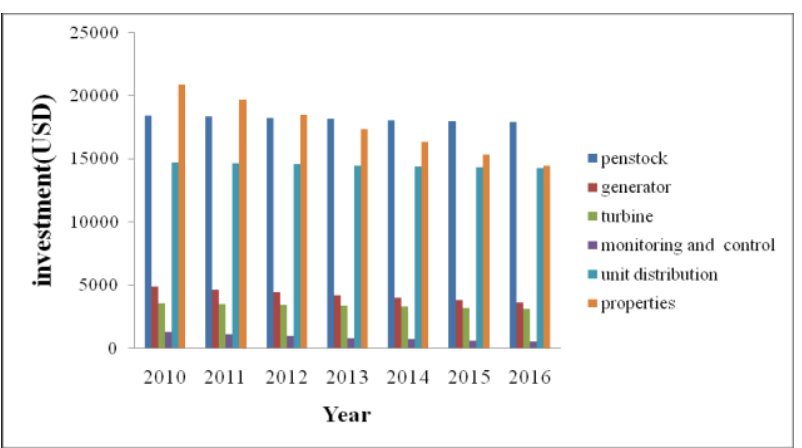

(a)

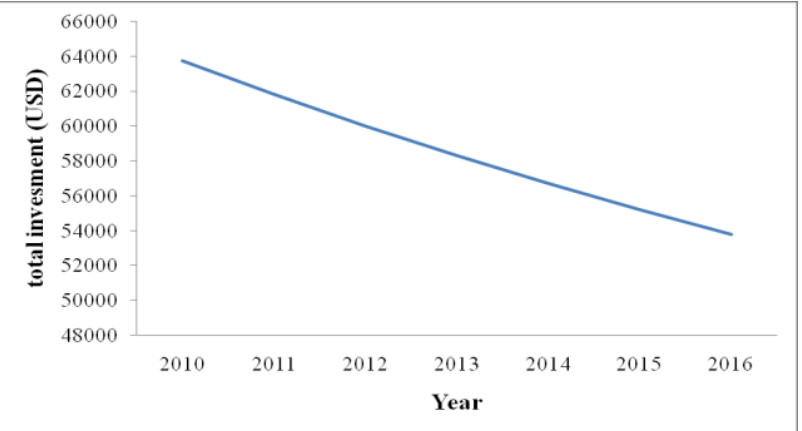

(b)

Fig. 4. (a) Decrease of MHP Investment Value (b) Decrease of Total MHP Investment Value

\section{Technical Feasibility and Ergonomics Aspects}

Curugmuncar II MHP is managed by an organization formed by the village community. The village head is responsible as a guardian. Next there is the structure of chairman, treasurer secretary, and two operators. The ability to master the maintenance of waterways consists of understanding the maintenance of diversion weir and intake, settling basin / sand trap, headrace, headtank, spillway, penstock, turbine, control valve, trailrace. The capability of controlling the power plant unit consists of spare part of the generating unit, installation of generating unit, maintenance and repair of electric generator, AVR (Automatic Voltage Regulator), panel / instrumentation, mechanical transmission, safety and environment of power plant unit. The ability to master electrical transmission system maintenance consists of wiring system, electrical transmission system spare parts, installation electrical transmission system, and safety and environment electrical transmission system. The management capability of MHP's management consists of safety and environment, financial, technical, logistics, administrative, quality, human resources, communication and public relations. Assessment of each component aspect is presented in the following figure: 


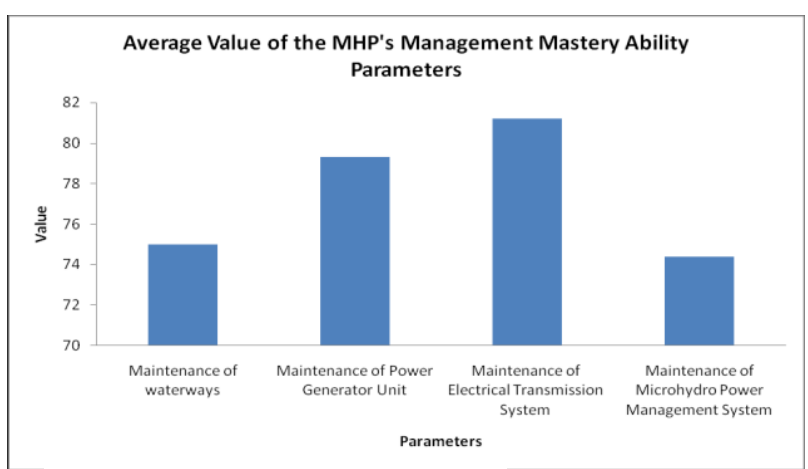

Fig. 5. Management Competency of MHP's Manager and Operators

Based on the assessment results, data obtained the value below the number 85 , it was imply that the professionalism management aspect still very less. Though it takes a number of at least 85 or more to know the professionalism in the management of MHP. Factors that influence the unprofessionalism in management was the lack of salaries, because of the management of MHP were based on the basis of family and non-profit. Based on the calculation results show that Curugmuncar II MHP has MDT 70.4 hours, MTBF 3780 hours, MTTR 21.25 hours, and Availability $98.1 \%$. In a study conducted by Sapkota, D et al in 2014 showed at Sunkoshi Hydro Power Station, Nepal conducted for four years showed availability of hydropower is $89 \%$ [15]. Furthermore, at Balimela Hydro Electric Power Station known availability $92 \%$ tested for 7 years [16].

Furthermore, the value of FOR Curugmuncar II MHP is known to be $1.9 \%$ so that the unavailability of electricity or the opportunity for electricity to die is 7 days / year, this is not in accordance with the Minister of Energy and Mineral Resources Decree of the Republic of Indonesia Number 58992016 which explains that the maximum electricity availability 1 day /year. The reliability criteria used are Loss of Load Probability (LOLP) smaller than $0.274 \%$ or equivalent with probalility outage 1 day of the year. In developed countries requires high reliability, many electrical systems are designed with LOLP criteria of 0.15 days or about 4 hours per year.

\section{Government Policy Aspects}

The implementation of micro hydro in Indonesia has not been widely regulated in national, provinces, or local regulations. This can be one of the weaknesses of micro hydro development built in the interior. Until now there is no special standard or special regulation that regulates the micro hydro institutional and micro hydro electricity tariffs enjoyed directly by the community. Therefore, the management of micro hydro in the village is implemented based on the agreement of the village apparatus and the manager.

On the other hand, the Law of the Republic of Indonesia Number 30 Year 2007 on Energy in Article 4 that New energy resources and renewable energy resources are regulated by the state and utilized for the greatest of the people's sincerity. In Article 19 that everyone has the right to gain energy and society, both individually and in groups, can play a role in the development of energy for the public interest. Furthermore, in the Law of the Republic of Indonesia Number 30 Year 2009 on Electricity, mentioned in Article 5 that the authority of the municipal government in the electricity sector involves the stipulation of regulation of regency/ municipality in the field of electricity.

Seeing the development of micro hydro technology that is widely applied in Indonesia, it is appropriate that local governments specifically regulate the management standards of MHP and tariffs established by considering the aspects of socio-economic in the region. It aims to maintain the sustainability of MHP and establish a good management pattern. However, not only local governments can establish a regulation for MHP, the village level government is also entitled to make village regulations that specifically regulate the management and tariff of the MHP in their village. So with the existence of clear rules, then hope management can be done more professional.

\section{Hydrology Aspects}

Based on data from the government of Pekalongan Regency, that rainfall in 2013 is on average per year 2,992 $\mathrm{mm}$, higher than in 2012 which experienced 2,243 $\mathrm{mm}$ rainfall. The average rainy day of 2013 is 143 days, higher than the average rainy day of 2012 of 120 days [17]. The highest rainfall occurred in Kecamatan Lebakbarang on average per year 5,321 $\mathrm{mm}$. Petungkriyono District is located in a mountainous area with Lebakbarang sub-district so it can be assumed that the rainfall that is sampled in Lebakbarang sub-district is almost similar to rainfall in Petungkriyono sub-district. Based on the analysis, it is estimated that the water cycle in Petungkriyono sub-district within 1 year is $39,151 \mathrm{M}^{3}$. The volume of water required by MHP for one year is about $3765 \mathrm{M}^{3}$. The volume of water required is about $10 \%$ of the water volume of one sub-district within a year.

\section{Water Quality of River Water, Clean Water Supply and Irrigation Aspects}

The river water used to drive turbines at Curugmuncar II MHP is sourced from waterfalls in the slopes of Mount Ragajambangan. The river water is utilized by the community as irrigating rice fields and also for daily needs such as washing clothes, bathing, and others. According to the information from the local community that the operation of the MHP does not interfere with their activities in irrigating rice fields and daily water use. The operation of MHP is known not to have a negative impact on the quality of river water. The measurement results show mean TDS of river water input $34 \mathrm{ppm}$ and output $31 \mathrm{ppm}$ with average $\mathrm{pH}$ of water output of 7.07 and $\mathrm{pH}$ of water output of 7.02. The output water flow from the powerhouse to the trailrace is reused as the next generation micro hydro source. MHP that does not cause residue is very environmentally friendly and 
supports forest conservation. It educates the community indirectly to preserve nature in the forest area as a water storage, so that the availability of water is always abundant throughout the year.

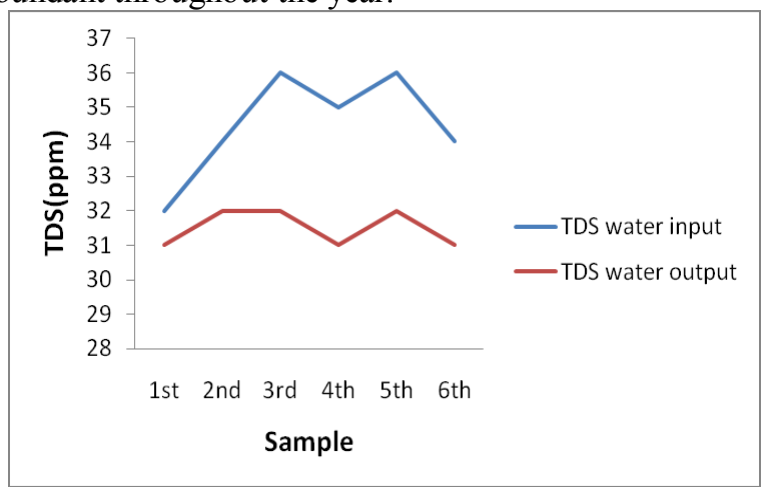

(a)

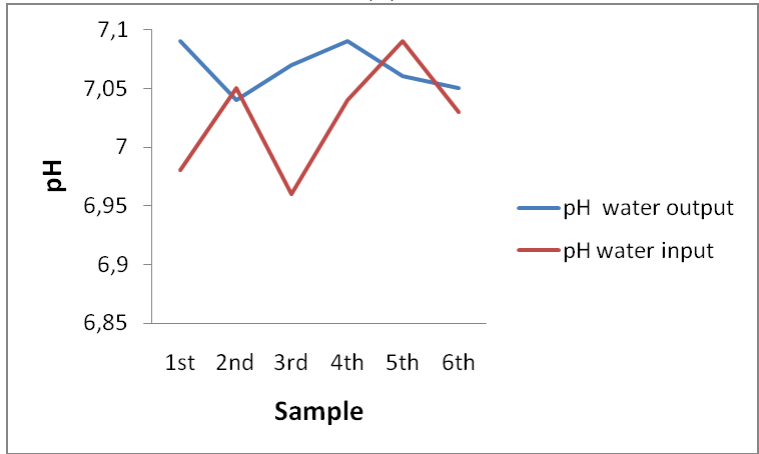

(b)

Fig. 6. Graph of River Water TDS and pH Condition from Input and Output the Power House

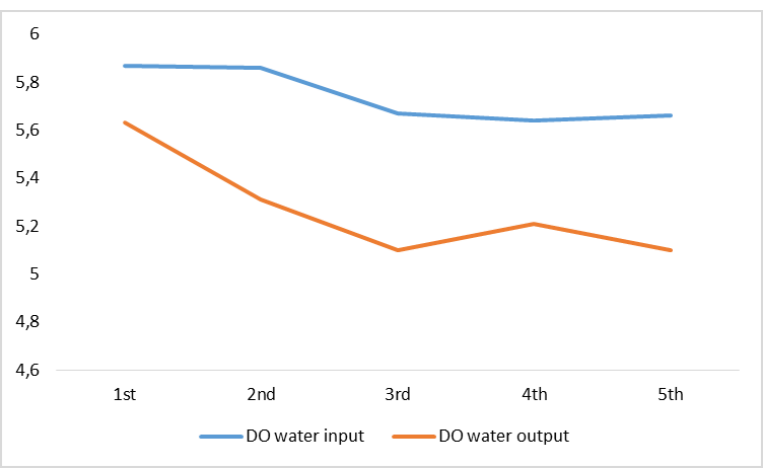

(a)

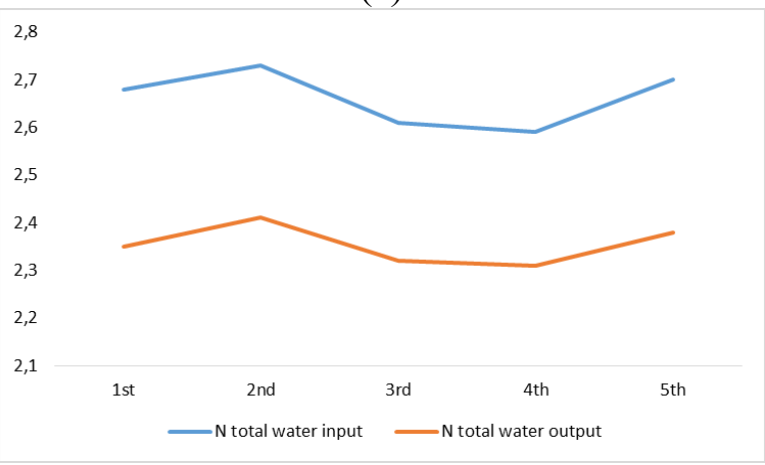

(b)

Fig 7. Dissolved Oxygen and Nitrogen Total Water from Input and Output the Power House
The condition of dissolved oxygen and total nitrogen content in water did not change significantly. Water samples are taken from the river stream at the input and output of the power house. The highest DO level of 5.87 on the input and the highest DO level of output was 5.63. The sample water also has the highest total nitrogen content of 2.73 (input water) and 2.41 (output water).

\section{Other Environmental Aspects}

The measurement results showed that the operation of Curugmuncar II MHP has no impact on the surrounding environment. Noise generated due to the operation of the system inside the power house averaged $74 \mathrm{db}$ and noise outside the power house averaged $56 \mathrm{db}$. The average temperature inside the power house is $38^{\circ} \mathrm{C}$ and the average temperature is outside $29{ }^{\circ} \mathrm{C}$. Activities around the power house is destined for agricultural land and quite far from the settlement so as not to interfere with community activities. The following figure shows a comparison graph between the noise and operating temperature of the Curugmuncar II MHP inside and outside the power house from a radius of $50 \mathrm{~m}$.

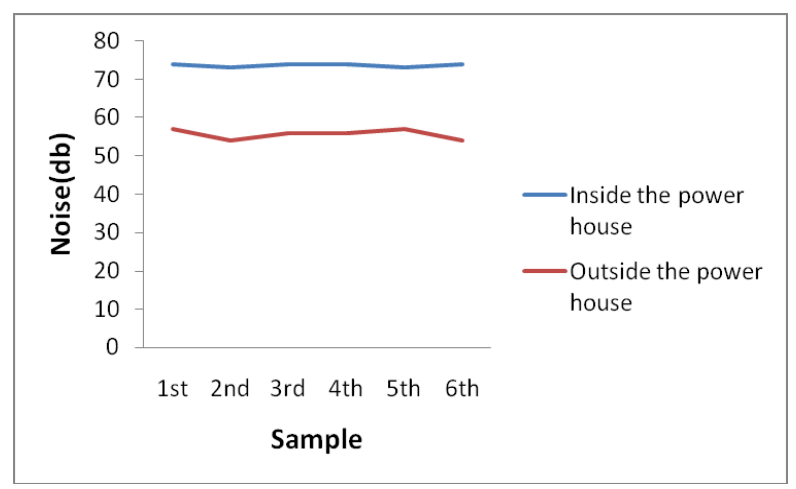

(a)

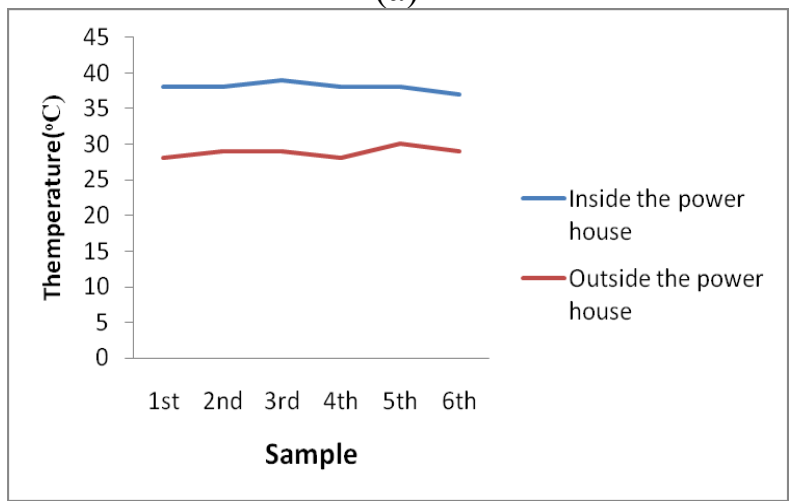

(b)

Fig. 8. Noise and Temperature Conditions from Input and Output the Power House

\section{Conclusions}

Curugmuncar II MHP with a power capacity of $100 \mathrm{KW}$ with the use of $50 \mathrm{KW}$ power. MHP serves 155 users with load capacity 2 A 220 volt AC. The community uses more lights as the lighting of houses and roads. MHP's operations has several environmental factors such as sociology, technically feasible, hydrology, physical and 
chemical water quality, ergonomics, economically feasible, irrigation, clean water supply, government policy, and environmental impact other. The factors support the MHP sustainability were: sociology, irrigation, ergonomics, clean water supply, physical and chemical water quality, hydrology, and government policy. The factors hamper MHP sustainability were: technically feasible, economically feasible, and government policy. From the results of the study shows that the environment aspects of MHP requires a professional management system to ensure the MHP sustainability.

\section{References}

1. Sazib Mollik, M.M. Rashid, M. Hasanuzzaman, M.E. Karim, M. Hosenuzzaman, Renewable and Sustainable Energy Reviews. Volume 65, November 2016, Pages 553-567, (2016)

2. Directorate General of Renewable Energy and Energy Conservation. 2016. EBTKE Statistics 2016. [online] http://ebtke.esdm.go.id/post/2017/03/07/1583/statistik. ebtke.2016 Accessed on May, 212017.

3. Directorate General of Renewable Energy and Energy Conservation. 2016. Buletin of Electricity Edition 46th. 2016. ISSN: 1979-6579[12].

4. Central Bureau of Statistics. 2015. Number of Village According to the Presence of Family of Electricity Users and Source of Lighting of Village Main Road. [online] https://www.bps.go.id/linkTabelStatis/view/id/1759 Accessed on 21 Mei 2017.

5. C. L Azimoh, P.Klintenberg, F.Wallin, B. Karlsson, C.Mbohwa, Energy Conversion and Management. [110] Pp. 268-277, (2016)
6. U. Akpan, M. Essien, S.Isihak, Energy for Sustainable Development [17] 5. Pp 504-509, (2013)

7. T. Slough, J. Urpelainen, J. Yang. 2015. Light for all? Evaluating Brazil's rural electrification progress, 2000-2010. Energy Policy. [86]. Pp. 315-327

8. B. Liddle and P. Sadorsky, How much does increasing non-fossil fuels in electricity generation reduce carbon dioxide emissions?. Applied Energy. [197] pp. 212221, (2017)

9. Rohani, H., \& Roosta, A. K. Calculating Total System Availability. [online] https://pdfs.semanticscholar.org. Accessed on June, 5, 2017

10. Stanley, S. 2011. MTBF, MTTR, MTTF \& FIT Explanation of Terms. IMC Network, pp16.

11. Office of the Assistant Secretary of Defense for Logistics \& Materiel Readiness. [online] http://www.acq.osd.mil//og/mr/mean_down_time.html . Accessed on June, 5, 2017

12. Crouse-Hinds, C. Availability, Reliability, SIL. Eaton, TX, US.

13. Humble, T. X. (1997). Availability, Reliability, Maintainability, and Capability.

14. Billinton, R. (1970). Power system reliability evaluation. Taylor \& Francis.

15. D. Sapkota, T. R. Bajracharya, \& M. C. Luintel, In Proceedings of IOE Graduate Conference (pp. 197202), (2014).

16. S. Dash, \& D. Das, (2014). Availability Assessment of Generating Units of Balimela Hydro Electric Power Station (510 MW)-A Markovian Approach. Volume 3 Issue 2-February 2014, 44.

17.Pekalongan Regency Goverment. 2017. Iklim. [online] http://www.pekalongankab.go.id. Accessed on June, 5, 2017 